\title{
THE U.S. BALANCE OF PAYMENTS- A FINANCIAL CENTER VIEW
}

\author{
ARTHur B. LAFFER*
}

\section{INTRODUCTION}

Since I949, the U.S. balance of payments has been characterized by over-all deficits using either the "official settlements" or "liquidity" definitions. ${ }^{1}$ The United States has typically had current account surpluses which were more than offset by capital account deficits, thus resulting in the over-all deficits. Prior to 1958 , U.S. deficits were deemed "beneficial," ostensibly because there was a "dollar shortage" abroad. From $195^{8}$ to the present, these same deficits were considered to be "harmful" because of a "dollar glut" abroad. In response to the sharp turnaround of the rest of the world's attitudes towards U.S. deficits and the rapid depletion of the U.S. gold stock, measures were taken to (a) reduce the U.S. deficit and $(b)$ stem the outflow of gold. The first measure taken was the complete prohibition of the ownership of gold (other than for industrial or artistic purposes) by a citizen of the United States. ${ }^{2}$ This was followed by a myriad of measures including devaluation of the defense, aid, and travel dollars, the interest equalization tax, and the voluntary controls on capital movements. The most recent step taken was the January r968 mandatory control program which applied to virtually all of the categories of the private U.S. capital accounts although a few regions were left unaffected.

All of the balance of payments measures taken between 1958 and the present were intended to "improve" the U.S. balance of payments position. Judging by the present discussions of the U.S. balance of payments, the problem appears to be far from "solved." In fact, one might argue that these measures have had little impact on the U.S. balance of payments position. More controls and other plans, which are intended to improve the U.S. balance of payments, are presently under serious consideration. It is the contention of this paper that the balance of payments controls, imposed during the past decade, have had little or no effect on the U.S. balance of payments per se. The concern over the U.S. balance of payments arises because of a fundamental misunderstanding of the U.S. position in the world-that of the world's financial intermediary. 3 Any problem that we actually face would be more accurately

- Assistant Professor of Business Economics, University of Chicago.

1 The "liquidity" basis includes as below-the-line accounts: ( $\mathrm{x}$ ) changes in gold, convertible currencies, and IMF gold tranche position, (2) changes in liabilities to foreign official holders, and (3) changes in liquid liabilities to private foreigners. The "official settlements" basis includes item (3) as an abovethe-line account.

${ }^{2}$ In the I930s U.S. citizens were prohibited from owning gold within the borders of the United States. In $196 \mathrm{r}$, the law was extended to prohibit ownership anywhere.

${ }^{3}$ The original article on this view of the balance of payments is Despres, Salant, \& Kindleberger, The Dollar and World Liquidity-A Minority View, THE Economist, Feb. 5, I966, at 526. The basic 
associated with the role of gold in the international monetary system and not with the existence of U.S. deficits. The measures to "cure" the U.S. payments deficits, although they have not cured the U.S. balance of payments, have contributed significantly to the misallocation of world resources.

Due to limited space it would be impossible to present a comprehensive representation of alternative views of the U.S. balance of payments. In the first section I shall attempt to formulate an analysis of the U.S. balance of payments along the lines of the international financial intermediation hypothesis. The second section deals with the implications of the international financial intermediation hypothesis in light of the actual empirical behavior of the U.S. balance of payments. The final section deals with the effects of the U.S. balance of payments controls in both theoretical and empirical terms.

\section{I}

\section{The Internatronal Financial Intermediation Hypothesis}

The role of the dollar as the world's leading currency was unambiguously established after World War II. In 1967 approximately twenty per cent of all world trade was directly with the United States. As both a world supplier of goods and a demander of goods the United States is the single most important nation. Although important to the United States, international trade in goods and services is a small fraction of the total U.S. market. In 1967 exports and imports were only 4.0 and 3.6 per cent respectively of total U.S. GNP. For other western countries international trade represents a much higher proportion of their respective markets. Thus, the United States is the largest absolute participant in world trade and simultaneously has the least proportional reliance on world trade. Stated alternatively, the United States most resembles a closed economy and at the same time has the greatest impact on foreign markets.

The small proportional reliance of the United States on world trade and the large absolute importance of the United States in world markets imply that the United States to a large extent determines the relative, as well as the absolute, prices of goods in the world. Within the United States, the domestic market dominates to such an extent that the relative and absolute prices of internationally traded goods must conform to their domestic counterparts. In the rest of the world the exact reverse tends to occur. The dominance of international trade tends to make foreign internal markets adjust to the internationally traded goods. Thus, to a large extent, relative and absolute prices reflect the conditions of the U.S. market. For foreigners, this tends to make the dollar a desirable asset as both an international means of payment and as a store of value.

The same type of effect has occurred with respect to financial assets as has work on the theory of financial intermediation is E. Shaw \& J. GurLey, Money in a Theory op FinancB (Ig60). 
occurred with goods. Under the system of pegged exchange rates the U.S. domestic capital market has come to dominate the major capital markets of the convertible currency countries. This again tends to make the dollar a desirable international asset relative to other currencies.

The basic assertion of the proponents of the international financial intermediation hypothesis (henceforth referred to as IFI) is that the U.S. capital market is the single most efficient capital market and that the U.S. dollar is internationally the most acceptable means of payment. The assertion concerning efficiency implies that in the U.S. capital market, financial intermediary lending rates (those rates facing private borrowers) are as low as or lower than lending rates prevailing in any other capital market and that financial intermediary borrowing rates (those rates at which private lenders can lend) are as high or higher than borrowing rates prevailing in any other capital market. ${ }^{4}$ This basic assertion or assumption provides the IFI hypothesis with its unique conclusions. ${ }^{5}$

\section{A. The Basic Model}

Imagine that each convertible currency economy other than the United Statesthe world's international financial intermediary-has four basic markets-money, bonds, goods, and labor. Imagine also that these commodities are gross substitutes. ${ }^{6}$ In general, labor is thought to be immobile among countries in the short run. I shall assume, therefore, that the labor market in each country is always in equilibrium. Via Walras' law we know that if an economy is in equilibrium in any two of the three remaining markets it must also be in equilibrium in the third. On a more intuitive basis, it follows that if an economy is precisely satisfied at going prices with, say, its stock of goods and bonds then it must also be satisfied with its stock of money. If it were not satisfied with its stock of money then it must be willing to give up bonds and/or goods to acquire additional money balances or vice versa. The price of money can be thought of as the inverse of the price of bonds (the interest rate) or of goods.

\section{Adjustments in a Closed Economy and in a Pegged Exchange System}

Within a closed economy adjustments in the money, bonds, and goods markets occur in the short run through price changes and in the longer run through quantity and price changes. This is not entirely true in the Keynesian view of a closed economy. In the world of Keynes, the prices of goods are assumed to be inflexible

\footnotetext{
'Another way of stating this proposition is that under autarky the gross margins in the United States would be smaller than those in any other market.

Naturally, the assumption as stated above is somewhat exaggerated insofar as this need not be true at each and every moment of time. The IFI hypothesis does, however, require that this assertion, in general, be correct.

- The gross substitutability assumption basically disallows an exogenous increase (decrease) in the excess demand for one commodity leading to an increase (decrease) in the excess demand for any other commodity.
} 
in the short run. Thus quantity adjustments substitute for price movements even in the short run. Given a short fall of effective demand, the level of output tends to fall while the price of goods remains unchanged. By making each country an open economy under pegged exchange rates we do not need to enter the debate between the Keynesians and the Quantity Theorists. It will, nonetheless, be helpful to work through an example in a closed economy.

If a closed economy is in equilibrium in the three relevant markets-money, bonds, and goods-what will happen if the supply of money increases? Given the initial demand for money, which depends upon the level of real goods production, the price of goods, and the interest rate on bonds, we would have an excess supply of money. The economy as a whole would want to exchange money for bonds and/or goods. Insofar as the economy wants to exchange money for bonds and/or goods this implies an excess demand for bonds and/or goods. In the bonds market the excess demand for bonds will be reflected in a rise in the price of bonds and a fall in the rate of interest on bonds. In the goods market an excess demand for goods will be reflected in a rise in the price of goods or, if the supply of goods is somewhat price elastic over some range, in an increase in the quantity of real goods production. The fall in the interest rate on bonds, the rise in the price of goods, and the increase in the quantity of real goods production, all lead to an increase in the demand for money. This process will continue until the demand for money has increased by the exact amount of the initial increase in the supply of money. At that point the system will be back in general equilibrium.

What happens now if all the economies in the world are precisely the same as the economy described above and are connected by pegged exchange rates which for the time period under consideration do not change. The principal feature of a pegged exchange system is that governments are willing to buy and sell foreign exchange at a pegged price in terms of their own currencies. ${ }^{7}$ Let us also assume that no one expects the current foreign exchange prices to change. In any one small country an increase in the quantity of money will lead to very different results with pegged exchange rates than it did in a closed economy. If there is an increase in the supply of money we have an excess supply of money and excess demands for bonds and goods. The excess demand for bonds will lead to an incipient rise in the price of bonds. An actual increase in the price of bonds is no longer possible. As soon as upward pressure on the price of bonds appears, foreigners, who previously supplied bonds to their own markets, would now supply bonds to this market. The reason for this is that they can obtain greater proceeds, given their interest costs, in the market with the incipient price rise in bonds. Simultaneously, on the demand side of bonds, domestics who want to purchase additional bonds will purchase them from abroad. If there is an incipient price rise of bonds in the domestic market they can

\footnotetext{
${ }^{7}$ Under our present system, virtually all currencies are pegged to the U.S. dollar, and the dollar price of gold is fixed by the United States.
} 
acquire bonds abroad at a lower price or with a higher rate of return. The end result will be, considering only the bonds and money market interaction, that bonds will be imported while some of the increase in domestic money balances will be exported. If the country in question is sufficiently small, all this can happen without any significant change in the price of bonds or, alternatively, the interest rate.

On the goods market side the reaction will be similar. The increase in the supply of money will lead to an excess demand for goods. The public in attempting to acquire more goods will precipitate an incipient price rise in the goods market. With the exchange rate being pegged, foreigners seeing higher prices in this market will export more goods and services. Domestic importers, likewise, will seek out the lowest prices and thus will turn to foreign markets and import more. Domestic imports will increase. Domestic producers of export goods, seeing the incipient price increases, will sell more at home and less abroad. Likewise, foreigners who purchased goods from this market will reduce their purchases because of the price rises. Thus, exports will decrease. With an increase in imports and a decline in exports the current account will deteriorate thus reflecting an exchange of the excess money balances for goods and services. As with bonds, this process can happen without any significant change in the price of goods.

The interesting result under pegged exchange rates, given an increase in the domestic money supply, is that the quantity of bonds and goods increases until the economy is back in equilibrium. If the economy is sufficiently small relative to the rest of the world there will not be any significant changes in the world rate of interest or the world price of goods. The balance of payments, however, will have worsened by the amount of the net purchases of bonds and goods. Foreigners who receive the domestic money balances for their bonds and goods will convert their newly acquired money balances into their own currency denominations. This requires that they take their newly acquired money balances and exchange them at either their own or at the domestic central bank. Thus, the domestic central bank will tend to lose foreign exchange reserves, and foreign central banks will tend to accumulate claims on the domestic central bank. Either way, a balance of payments deficit occurs. In the first case the domestic country will lose gross as well as net reserves. In the second case only the net reserve position will be lower, the net reserve position being defined as total reserves of a country less its liabilities in the reserves of other countries.

The example taken above can be generalized. If a country has an incipient excess demand for or supply of money its balance of payments will improve or worsen respectively. Naturally the definition of the below-the-line accounts must be appropriate for the definition of money. ${ }^{8}$ Insofar as a country has its excess demand for

\footnotetext{
${ }^{8}$ If, for example, we use the "basic balance" definition of the balance of payments, deficits would be considered as the net outflow of all assets of maturity of less than 366 days (including gold). In this case the implication is that money consists of all assets of maturity of 365 days or less (including gold). Similarly, alternative definitions of money imply alternative definitions of the balance of payments.
} 
(supply of) money matched by an excess supply of (demand for) goods the surplus (deficit) will show up in the current account-the balance on goods and services. If the excess demand for (supply of) money is matched by an excess supply of (demand for) bonds the surplus (deficit) will show up in the capital accounts. If, however, there is an excess demand for or supply of goods matched by an excess supply of or demand for bonds, the over-all balance of payments will not be affected. The improvement or worsening in the current account will be matched by the opposite movement in the capital account. If exchange rates are pegged and are expected to remain the same, the prices of goods and bonds will hardly move at all, but there will be international flows. Once we concede that the country in question is no longer very small relative to the rest of the world, there will be effects on the price of bonds and the price of goods. The effects, however, will be felt throughout the world and not just in the country in question.

\section{The IFI Hypothesis and the Pegged Exchange System}

The IFI hypothesis begins where this basic analysis leaves off. As stated earlier the unique assumption is that the United States is the world's most efficient financial intermediary. We also stated that due to the enormous size of the United States, its liabilites (dollars) are a preferred asset. The preference for dollars on the part of foreigners reveals itself in the realm of international trade. International trade, even between non-U.S. countries, takes place in a dollar numeration. This leads to a foreign demand for liquid dollar balances for transactions purposes. Thus the foreign demand for money balances can be segmented into two parts. Foreigners demand U.S. dollar money balances for international trade purposes and also demand money balances denominated in their own individual currencies for domestic transactions purposes. ${ }^{9}$

In a static environment private foreigners will have a stock of dollar balances (U.S. short-term liabilities to private foreigners) and a stock of money balances in their own currency denominations. There will also be a two-directional flow of goods and services between the United States and foreign countries. Likewise, there will be stocks of U.S. liabilities to and claims on foreigners. Foreign central banks will have gold and liquid dollar reserves. When we introduce growth the balance of payments effects become clear.

Growth in nominal international trade will lead to an excess demand for U.S. dollar money balances on the part of foreigners. The demand for U.S. dollar money balances on the part of foreigners should depend upon the level of real international transactions, the world price level, and the world rate of interest. Given that the foreign internal level of transactions remains unchanged, growth in the international

\footnotetext{
${ }^{\circ}$ At present, we are abstracting entirely from the existence of dollar capital markets existing in countries other than the United States. The actual size of the Eurodollar markets and their pervasiveness makes this abstraction' somewhat unrealistic but will not materially affect the conclusions.
} 
level of transactions will lead, pari passu, to an excess demand for U.S. dollar balances and an excess supply of bonds. Due to the efficiency of the U.S. capital market, foreigners will float bonds in the U.S. capital market. With the proceeds from the bond sales, foreigners will augment their dollar deposits within the United States.

A similar reaction will occur if for some reason the rate of interest on bonds in the U.S. capital market were to fall. The fall in the U.S. rate of interest would lead to an excess demand for dollar balances on the part of foreigners. After this fall in the U.S. interest rates it would cost foreigners less in forgone earnings to hold money balances. Again the excess demand for U.S. dollar balances would be satisfied by the export of bonds to the United States. The proceeds of the bond sales would be used to augment foreign dollar balances. Regardless of whether the increase in the foreign demand for U.S. dollar balances came about via an increase in international transactions or by a fall in the rate of interest, we would expect to find a U.S. capital outflow (U.S. importation of foreign bonds) and a foreign short-term capital inflow (the increase in foreign dollar balances). In the balance of payments statistics of the United States this would be reflected as a "liquidity" deficit. Using the liquidity definition of the balance of payments, U.S. capital outflows are included as an above-the-line item whereas foreign short-term capital inflows are a below-theline account. On the "official settlements" definition of the balance of payments the reaction described above would be reflected as one capital movement offsetting another without a resulting deficit. Private foreign short-term capital inflows are included as an above-the-line account.

Growth in foreign income not associated with international trade will also have effects on the U.S. balance of payments. In general we would expect that an increase in the rate of growth of a country would lead to an excess demand for goods and money. Via the interaction of the accelerator and multiplier, an increase in the rate of growth of income should lead to an excess demand for goods and services. If one prefers to work with permanent income or total wealth, an increase in the annual rate of growth of income will lead to a larger increase in the permanent income. With the demand for goods a function of a permanent income, this leads to an excess demand for goods.

Growth in foreign income will also lead to an excess demand for foreign-currencydenominated money balances. With the increase in foreign internal income foreigners will need greater money balances for the now higher level of transactions. To the extent that foreign growth leads to foreign excess demands for both goods and money we must find a foreign excess supply of bonds. The foreign excess demand for goods will lead to a U.S. current account surplus or alternatively to a foreign current account deficit. This will be financed by the export of bonds to the United States-a net U.S. capital outflow. The excess demand for money balances on the part of foreigners will also lead to the export of bonds to the U.S. by foreigners.

The unique feature here, however, is that private foreigners wish to accumulate 
money balances in their own currency denominations. Thus, they will convert some of the proceeds from the sale of bonds into their own foreign currencies at their central banks. The remaining portion of the proceeds will be used to finance the net purchases of goods. The balance of payments effect of foreign growth will be an improvement in the current account of the United States and a deterioration in the capital account which more than compensates for the improvement in the current account. Using either the "liquidity" or "official settlements" definitions of the balance of payments, the United States is in deficit. Foreign central banks will have accumulated liquid dollar assets without any corresponding liabilities to the U.S. government. The private foreign sector, however, has accumulated a net liability to the U.S. private sector to the full amount of the U.S. capital outflows. The difference between the change in net U.S. liabilities to official foreigners and the change in net U.S. claims on private foreigners will be the balance on current account.

If the IFI hypothesis is correct we can think of the U.S. balance of payments as being the residual of the balance of payments of the rest of the world. An excess demand for goods matched by an excess supply of bonds in the rest of the world implies a U.S. current account surplus and a U.S. capital account deficit of approximately the same magnitude. An excess demand for foreign-currency-denominated money balances matched by an excess supply of bonds in the rest of the world implies a U.S. capital account deficit and an increase in the foreign official holdings of U.S. dollar liabilities-an official settlements as well as a liquidity deficit. An excess demand for dollar-denominated money balances matched by an excess supply of bonds on the part of the rest of the world implies a U.S. capital account deficit and a private foreign short-term capital account surplus-a liquidity deficit but not an official settlements deficit.

\section{B. Trading of Financial Assets}

Up to this point the discussion has been focused upon the allocation of realı resources-goods, money, and bonds-between the United States and the rest of the world. Due to the assumption that the United States has the most efficient capital market and that the dollar is the most acceptable means of international payment, we end up with the United States being the residual country in the over-all balance of payments. Although this is by far the most important part of the IFI hypothesis for our purpuses, there is an additional implication. The existence of the efficient U.S. capital market allows foreigners simultaneously to issue and to purchase financial assets both inexpensively and with the asset characteristics they prefer. Although this trading of assets will not affect the balance of payments, it can have very important beneficial effects on the foreign countries.

Foreign borrowers clearly gain from the use of the U.S. capital market. The reduction in the effective cost of debt may, indeed, be quite substantial. Because of the 
U.S. capital market's size and diversity as well as efficiency, foreign liability issuers are able to issue almost any type of liability they wish, in any quantity they wish, and still receive the highest price for their liabilities. Not only do they receive the highest price for their liability issuances, which clearly improves the welfare of foreign issuers, but they also have the additional nonpecuniary benefits of making the liabilities precisely fit their own needs. Likewise, the thickness of the market means that they do not have to worry about the size of their issue and the effects on the market price of their liability either at the time of issue or when they might wish to refinance at a later date.

Simultaneously, foreign lenders gain substantial benefits from lending in the U.S. capital market. By receiving higher explicit yields on financial assets, foreign lenders improve their direct pecuniary returns. Also, the existence of a very diverse selection of assets allows foreign lenders to get precisely what they want and thus increases their nonpecuniary yields. The thickness of the market also makes it easier for the asset holder to sell the asset at a fairly stable price in the future if the need arises. Foreign lenders clearly gain from the use of the U.S. capital market.

The trading of financial assets through the U.S. capital market is also one of the principal allocators of real resources among foreign countries as well as among the residents of any single foreign country. Thus the trading of financial assets is symmetrical with the analysis of the basic model. The U.S. capital market in the analysis of the basic model allocates real resources between the United States and foreign countries, whereas for the trading of financial assets the U.S. capital market allocates real resources among foreigners. The analysis of the basic model has direct implications for the U.S. balance of payments deficits and surpluses. The trading of financial assets, however, does not affect net flows but does affect gross flows. In spite of the observation that the trading of financial assets is not important with respect to the over-all balance of payments of the United States it is an important factor in determining the aggregate effects of the controls program.

\section{Equilibrium and Problems}

Equilibrium in the system previously described is comparable to the notion of equilibrium in a closed economy. Just as the United States runs large deficits with the rest of the world so have eastern states run deficits with respect to the western states and other more rapidly developing states. The deficits and surpluses among the many states of the United States, however, have not been a sign of fundamental or even temporary disequilibrium, but merely reflect different growth potential. Disequilibrium in such a system reveals itself in excessive unemployment or inflation or the failure to attain other social goals. ${ }^{10}$

Balance of payments deficits per se imply nothing whatsoever about the United

\footnotetext{
${ }^{10}$ See Salant, Capital Markets and the Balance of Payments of a Financial Center, in W. FelLNER et al., Maintaining and Restoring Balance in International Payments I77-96 (1966).
} 
States being in or out of equilibrium. Under conditions of world growth the United States generally would be expected to have deficits using either the liquidity or the official settlements definition of the balance of payments. Naturally, the magnitude of U.S. deficits will depend upon the monetary policies of the foreign countries and the United States. Large U.S. deficits will be attained when foreign countries attempt to have tight monetary policies and when the U.S. has an easy monetary policy. ${ }^{11}$ Under these circumstances foreigners will attempt to augment their domestic currency money balances by large amounts. Small U.S. deficits or possibly even surpluses will be attained when foreign countries loosen up in the money market and when the United States has a tight money market. U.S. deficits, therefore, depend simultaneously upon U.S. and foreign monetary policies.

Simultaneously, the world's rate of inflation depends upon U.S. and foreign monetary policies. The world's rate of inflation will be high if both the United States and foreign areas have easy monetary policies. If both the United States and foreign areas have tight monetary policies over a period of time there will be a tendency for unemployment to persist. Neither tight monetary policies nor loose monetary policies, however, necessarily coincide with large or small deficits in the U.S. balance of payments. It is conceivable, in fact, that either excessive inflation or excessively high unemployment could persist with the United States having either balance of payments surpluses or deficits. Likewise, either U.S. surpluses or deficits are consistent with low rates of inflation without excessively high unemployment. Thus, according to the analysis above, one should more accurately focus on inflation or unemployment as a signal of an undesirable position rather than on the U.S. balance of payments position. ${ }^{12}$

The present international payments system is not solely a system of pegged exchange rates. If there were no additional encumbrances to the system, the preceding analysis would stand by itself. This, however, is not the case. Nearly all convertible currency countries fix the price of their own currency in terms of dollars, and, in addition, the United States has attempted to peg the dollar price of gold.

The basic problem with the present system rests on the fixed dollar price of gold and the international distribution of dollar assets and liabilities between foreign private and official sectors. After international financial intermediation has occurred, the private sector in the United States will have net claims on the foreign private sector. Private foreigners, however, will have exchanged some of their dollar assets-acquired by issuing debt in the United States-for foreign-currency-denominated assets. Official foreigners will thus have net liquid dollar assets. Historically, these liquid dollar assets have increased at a much greater rate than the world's monetary gold stock. By fixing the price of gold in terms of dollars the United

\footnotetext{
11 "Easy" and "ight" monetary policies refer to the relationship between money and income.

${ }^{12}$ Insofar as the problem is a joint problem between U.S. and foreign monetary policies, so must the correction be jointly undertaken.
} 
States has created the perfect speculative opportunity. By virtue of the U.S. government's sovereignty over the issuance of dollars it is impossible for the dollar price of gold to fall due to market pressure. This sovereignty, however, does not exist for gold, and it is conceivable that the United States will run out of gold, forcing the dollar price of gold to rise. This reduces the willingness of official foreigners to hold their international reserves in dollars and to accumulate even more, thus precipitating the so-called U.S. balance of payments problem.

\section{II}

\section{The U.S. Balance of Payments, I958-I968, and the IFI Hypothesis}

The basic propositions of this paper are as follows: (a) Relative growth in the United States and abroad determines to a large extent the U.S. current account position. (b) The current account surplus or deficit will be financed by above-the-line capital flows. (c) The rate of growth of world trade and changes in the U.S. rate of interest determine to a large extent foreign short-term capital inflows into the United States. (d) Foreign internal growth-not relative to the United States-and changes in the level of U.S. interest rates are major determinants of the U.S. "official settlements" deficits. In the next few paragraphs, I shall attempt to show how the U.S. actual balance of payments experience from $195^{8}$ to the present fits in with the basic propositions of the IFI hypothesis. At present, due to the paucity of accurate data, it is virtually impossible to demonstrate proposition " $\mathrm{d}$ " with respect to the United States alone. ${ }^{13}$

In Figure I the ratio of the U.S. current account surplus to U.S. GNP on an annual basis is plotted for the years $195^{8}$ through I968. On the same figure the annual differential between the foreign rate of growth and the U.S. rate of growth is plotted for these same years. Both series move remarkably well together over the period $195^{8}$ through 1968 . The only major exception appears to be 1967 when the United States had a temporary retardation in the rate of growth of GNP. All in all, it appears quite clear from Figure $I$ that the relative growth in the United States and abroad is highly correlated with the U.S. current account position.

In Figure 2 the U.S. current account position is plotted by year as is the U.S. above-the-line capital account position. These two series again move remarkably well together. When the U.S. current account improves, the capital account deteriorates and vice versa. From Figure 2 the movements appear to be approximately one for one. For an increase in the current account surplus of the United States, say by $\$ 500$ million, the expected deterioration in the capital account is approximately $\$ 500$ million. In general, it appears as though the U.S. current account surplus or deficit is financed by above-the-line capital flows.

\footnotetext{
18 In my paper, "An Anti-Traditional Theory of the Balance of Payments Under Fixed Exchange Rates" (1969, as yet unpublished), changes in gross reserves of countries are found to be highly correlated with changes in growth rates. This supports proposition "d" although it does not isolate the United States.
} 
FIGURE I

Ratio of U.S. Current Account Surplus to U.S. GNP, in Per Cent, by Years, 1958-r968 Foreign Rate of Growth Minus U.S. Rate of Growth, in Per Cent, by Years, x958-r968

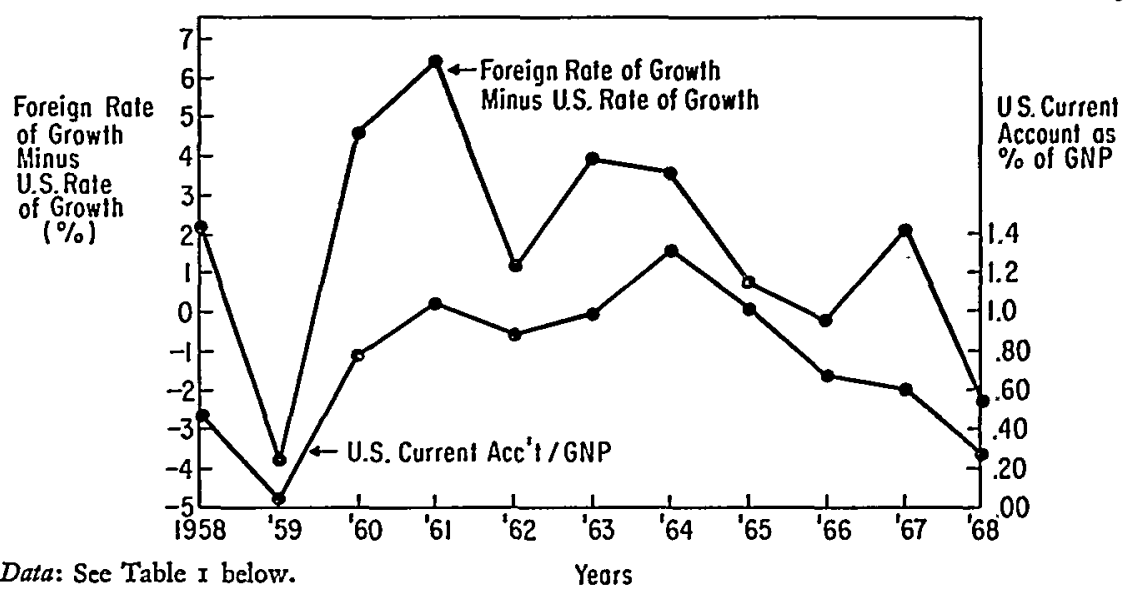

FIGURE 2

U.S. Current Account Surplus, by Years, 1958-1968, in Billions U.S. Above-the-Line Capital Account, by Years, 1958-1968, in Billions

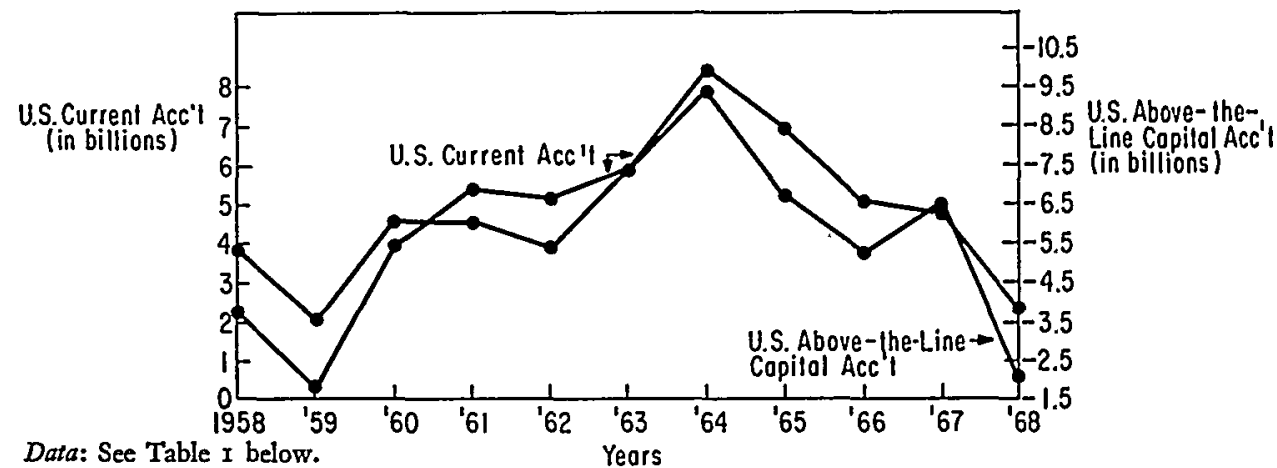


TABLE I

Data for Figures I AND 2

\begin{tabular}{|c|c|c|c|c|}
\hline \multirow[b]{2}{*}{ Year } & \multicolumn{2}{|c|}{ Data for Figure 2:14 In Millions } & \multicolumn{2}{|c|}{ Data for Figure 1:15 In Percent } \\
\hline & $\begin{array}{c}\text { U.S. } \\
\text { Current Account }\end{array}$ & $\begin{array}{c}\text { U.S. } \\
\text { Capital Account }\end{array}$ & $\begin{array}{l}\text { Foreign Growth } \\
\text { Rate minus U.S. } \\
\text { Growth Rate }\end{array}$ & $\begin{array}{l}\text { U.S. Current } \\
\text { Account as \% } \\
\text { of GNP }\end{array}$ \\
\hline 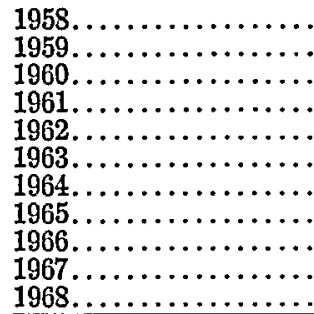 & $\begin{array}{r}2206 \\
147 \\
3970 \\
5458 \\
4985 \\
5812 \\
8409 \\
6901 \\
5080 \\
4768 \\
2395\end{array}$ & $\begin{array}{l}-5337 \\
-3625 \\
-6282 \\
-6256 \\
-5414 \\
-7347 \\
-9453 \\
-6894 \\
-5210 \\
-6530 \\
-2035\end{array}$ & $\begin{array}{r}2.2 \\
-4.2 \\
4.7 \\
6.5 \\
1.2 \\
3.9 \\
3.6 \\
0.7 \\
-0.2 \\
2.1 \\
-2.3\end{array}$ & $\begin{array}{r}.493 \\
.030 \\
.788 \\
1.049 \\
.890 \\
.984 \\
1.330 \\
1.008 \\
.680 \\
.604 \\
.278\end{array}$ \\
\hline
\end{tabular}

In an earlier study of private foreign short-term capital flows into and out of the United States, I was able to find a statistically and economically significant relationship between private foreign short-term capital inflows and changes in the level of world trade. ${ }^{16}$ When changes in non-U.S. Eurodollar liabilities were also included in the relationship the statistical significance of changes in the level of world trade was greatly improved. This tends to support the proposition that the rate of growth of world trade determines, to a large extent, foreign short-term capital inflows into the United States.

\section{III}

\section{The Controls Program and the Barance of Payments of the United States}

Even though the present system of controls covers most U.S. private capital accounts, it does not directly affect private foreign capital accounts. In the early stages of the U.S. controls program selected U.S. capital accounts had controls imposed upon them, whereas others remained uncontrolled. To my knowledge there has not been a comprehensive study of the mandatory control program which was imposed in January rg68. There have, however, been studies of the interest equalization tax and the voluntary foreign credit restraint program. ${ }^{17}$ The conclusions

14 The U.S. current account and capital account are from the 1969 Economic Report of the President, Table B-84, at 324-25, "Balance on Goods and Services," and the sum of ( $x$ ) "U.S. Government Grants and Capital Net," (2) "U.S. Private Capital Net," and (3) "Foreign Capital Net."

${ }^{15}$ The U.S. current income and GNP figures are from the 1969 Economic Report of the President. The growth rate figures, I957-I966, are from National Accounts of OECD Countries ro (I968). For r967 and 1968 these figures are from the 1969 Economic Report of the President and the weighted average of United Kingdom, Germany, Italy, France, and Japan dollar GNPs, Ig69.

${ }^{10}$ A. B. Laffer, Short-Term Capital Movements and the Voluntary Foreign Credit Restraint Program (1969, as yet unpublished).

${ }^{17}$ R. Cooper, The Interest Equalization Tax: An Experiment in the Separation of Capital Markets (Yale University Economic Growth Center Paper No. 78, r967); Laffer, supra note I6. 
reached by both studies were that over-all the controls had virtually no effect on the balance of payments because of substitution between different capital account categories.

In the case of the Voluntary Foreign Credit Restraint Program there was a marked reduction in U.S. private short-term capital outflows for approximately one year after the program's initiation. This was matched almost precisely by a repatriation of private foreign short-term deposits in the United States over the same period. The net balance of payments effect was negligible. With respect to the new mandatory controls program it is very reasonable to expect the same type of reaction to occur. The over-all balance of payments will probably not be affected very much if at all. As long as a sufficient number of loopholes remain-as they must because of the reluctance to control foreign capital-the over-all balance of payments will not be materially affected. There are, however, other much more important effects of the controls.

The existence of controls imposes heavy costs on countries which rely on the U.S. capital market, such as Japan, Latin America, and Canada. On the one hand, these areas have had their credit cut off, and, on the other hand, they have reduced their investments in the United States. These two occurrences are only symmetrical with respect to the over-all balance of payments of the United States. A reduction of balances held in the United States significantly raises the costs associated with financial intermediation and thus causes misallocation of real resources. No matter how inefficient it may be, foreigners are forced to provide their own internal financial intermediation due to the capital controls imposed by the United States.

Artificially raising the costs of borrowing in the United States also creates a tendency for foreigners to reduce their imports from the United States. This also represents a misallocation of resources from an efficiency standpoint. The controls also reduce the volume of the trading of financial assets through the United States capital market. Again it can easily be demonstrated that there are efficiency losses. The most ironic feature is that these controls apparently have not improved the U.S. balance of payments position. If we view international financial intermediation properly, the United States should have over-all balance of payments deficits. Foreigners as well as the United States gain from the U.S. role as the international financial intermediary. 